\title{
ANALISIS KEMAMPUAN PENALARAN MATEMATIKA SISWA PADA MATERI HIMPUNAN
}

\author{
Fungky Marian \\ Prodi Pendidikan Matematika, FKIP, Universitas Muhammadiyah Lampung, \\ Jl. Z.A. Pagar Alam No. 14 Bandar Lampung \\ e-mail: fungkymarian29@gmail.com
}

\begin{abstract}
Reasoning is a process of thinking to get a conclusion from an idea or ideas that can be justified. The purpose of this study was to determine how students' mathematical reasoning abilities in the set material. The method in this research is descriptive quantitative to describe and analyze how high the level of students' mathematical reasoning. The subjects of this study were students of class VII A SMP Negeri 2 Berbah. Based on the results of the study, it was found that the level of students' mathematical reasoning was still in the sufficient category, so it is necessary for a learning method that can stimulate students so that mathematical reasoning becomes better.
\end{abstract}

Keywords : mathematical reasoning, set

\begin{abstract}
Abstrak
Penalaran merupakan proses berfikir untuk mendapatkan sebuah kesimpulan dari gagasan atau ide-ide yang dapat dipertanggung jawabkan kebenarannya. Tujuan dari penelitian ini untuk mengetahui bagaimana kemampuan penalaran matematika siswa pada materi himpunan. Metode dalam penelitian ini adalah deskriptif kuantitatif untuk menggambarkan dan menganalisa seberapa tinggi tingkat penalaran matematika siswa. Subjek penelitian ini siswa kelas VII A SMP Negeri 2 Berbah. Berdasarkan hasil penelitian didapatkan bahwa tingkat penalaran matematika siswa Masih dalam kategori cukup, maka untuk itu perlu sebuah metode pembelajaran yang dapat merangsang siswa agar penalaran mateamtika menjadi lebih baik.
\end{abstract}

Kata kunci : penalaran matematika, himpunan 


\section{PENDAHULUAN}

penalaran merupakan kemampuan dasar yang harus dimiliki siswa, dalam setiap kegiatan pembelajaran matematika tidak akan terlepas dari penalaran [1]. Napitupulu, Dkk. menyatakan bahwa dengan menalar siswa dapat membangun pengetahuannya dan keterampilannya untuk memecahkan soal matematika dengan mudah [2]. Shivakumar \& Suvarma berpendapat bahwa kemampuan penalaran diakui sebagai kemampuan utama dalam menyimpulkan suatu gagasan atau ide untuk mendapatkan kesimpulan yang benar, untuk itu keterampilan menalar harus menjadi salah satu perhatian besar dalam dunia Pendidikan [3]. Sedangkan Rizqi \& Surya berpendapat bahwa kemampuan penalaran siswa sangat dibutuhkan untuk membuat sebuah kesimpulan dengan benar dengan menalar siswa dapat berfikir tentang bagaimana cara untuk membuat sebuah kesimpulan yang dapat dipertanggung jawabkan dari sebuah ide-ide atau gagasan yang telah didapatkan sebelumnya [4].

Namun pada kenyataanya dalam pembelajaran matematika masih didasarkan kepada system algoritma hafalan sehingga banyak siswa yang belum menguasai konsep pembelajaran matematika, banyak guru yang handal dalam mengajarakan matematika namun mereka tidak menyertakan pemahaman atau penanaman konseptual yang baik [5]. Penelitian Hidayat, Dkk mengatakan bahwa banyak siswa masih belum mampu untuk menyelesaikan soal dalam matematika dikarnakan siswa belum dapat menggunakan penalaran dengan baik, siswa hanya menggunakan sistem hafalam untuk menyelesaikan soal matematika [6]. Salah satu tujuan dalam pendidikan matematika yang paling penting menurut Erdem and Gürbüz adalah dapat menyelesaikan permasalahan-permasalah dengan menggunakan solusi yang efesien, salah satu yang sangat berpengaruh untuk mengambil sebuah keputusan yang tepat adalah dengan menggunakan penalaran, karna dengan penalaran yang tinggi siswa tersebut dapat menyelesaikan permalahan dengan cepat [7]. 
TIMSS adalah sebuah study internasional yang dimana bertujuan untuk mengukur sejauh mana kemampuan matematika dan sains untuk Negara tersebut. Dari data TIMSS Indonesia masih berada diurutan 45 dari 50 negara yang berpartisipasi pada study TIMSS, bila dilihat dari penacapaian peserta dididk indonesia pada aspek koqnitif penalaran (reasoning) hanya mencapai $20 \%$ hal ini harus mendapatkan perhatian lebih agar siswa tidak kesulitan dalam memahami matematika [8]. Maarif mengatakan bahwa materi dalam pembelajaran matematika hanya dipahami dengan mengggunakan penalaran sedangkan penalaran dapat dilatih menggunakan pembelajaran matermatika [9].

Penalaran matematika di kurikulum turki dalam jurnal Erdem [10] mengatakan bahwa siswa harus dapat menggunakan penalaran untuk menyimpulkan sebuah gagasan dengan cara menghubungkan antara symbol, pola defenisi, hubunngan dll. Permendiknas menyatakan bahwa tujuan pembelajaran matematika disekolah adalah untuk melatih siswa agar mampu untuk bernalar dengan membuat sebuah kesimpulan serta menyusun bukti yang kongkrit untuk mendapatkan jawaban yang valid atau dapat dipertanggungjawabkan [11].

Dalam penelitian Sukirwan, Dkk menjelaskan bahwa dalam pembelajaran matematika siswa belum menggunakan penalarannya dalam menyelesaikan permasalah matematika tersebut, kualitas penalaran siswa masih didominasi oleh penelaran imitative [12]. Tamura, Dkk Menyatakan pendapat bahwa faktor usia juga tidak mempengaruhi penalaran matematika seseorang bahkan usia yang lebih tua belum tentu mempunyai penalaran yang baik, faktor yang mempengaruhi penalaran siswa adalah seberapa sering siswa tersebut berlatih untuk meningkatkan penalarannya sedangkan dalam temuan [13].

Berdasarkan pemaparan diatas peneliti menyimpulkan bahwa penalaran itu sangat penting terutama dalam pembelajaran matematika, karna dengan penalaran siswa dapat menyelesaikan permasalah dalam matematika dengan mudah terutama pada saat mengerjakan soal yang mempunyai tingkat kesulitan yang cukup 
tinggi. penelitian ini dilakukan untuk mengetahui seberapa tinggi tingkat penalaran matematika siswa serta mengidentifikasi faktor apa saja yang mempengaruhi penalaran matematika siswa.

\section{METODE PENELITIAN}

Penelitian ini merupakan penelitian deskriptif kualitatif yang bertujuan untuk mengetahui gambaran dari kemampuan penalaran matematika siswa Tes yang diberikan untuk mengukur penelaran matematika siswa berupa soal esai sebanyak 5 soal, indikator tes penalaran matematika siswa menggunakan sebagaimana yang dicantumkan oleh P4TK Yogyakarta dalam Wardhani. Yaitu 1) siswa harus mampu memberikan alasan mengapa sebuah jawaban tersebut masuk akal (mengajukan dugaan). 2) siswa harus mampu membuat sebuah kesimpulan dari hasil penyelidikan atau penelitiannya (melakukan manipulasi matematika. 3). Siswa harus mampu membuat kesimpulan dari informasi yang sudah di dapat 4). Siswa harus mampu menarik kesimpulan dari pernyataan. 5). Siswa mampu memberikan argument yang dapat di pertanggung jawabkan menggunakan berpikir deduktif induktif.6). siswa harus menggunakan data yang valid untuk mendapatkan kesimpulan yang dapat dipertanggungjawabkan [14]. Subjek dari penelitian ini adalah siswa kelas VII A SMP Negeri 2 berbah.

Adapun prosedur dalam penelitian menggunakan langkahlangkah sebagai berikut: pada tahap persiapan. 1) melakukan observasi, 2) membuat kisi-kisi penalaran matematika,3) membuat intrumen penelitian berupa soal Esay sebanyak 5 soal. Pada tahap pelaksanaan.1). memberikan soal tes kemampuan penalaran matematika kepada siswa.2) menganalisis jawaban siswa 3). Mewawancarai beberapa siswa sesuai dengan pengelompokann tingkat kemampuan (Atas, Menengah, Bawah. Pada tahap pegelolaan data: 1) melakukan analisis data kuantitatif dan kualitatif. 2) mendeskripsikan 
hasil dari pengelolaan data. 3) menarik kesimpulan dari data yang diperoleh.

Untuk mengetahui tingkatan kemampuan penalaran matematika nilai kemampuan matematika siswa dikonversikan dalam bentuk kuantitatif dengan menggunakan pedoman penskoran seperti pada Tael 1. Berikut ini.

Table 1 Pedoman Penskoran Tes Penalaran Matematika

\begin{tabular}{cc}
\hline Nilai & Kategori \\
\hline $81>100$ & Sangat Baik \\
$61-80$ & Baik \\
$41-60$ & Cukup \\
$21-40$ & Kurang \\
$0-20$ & Sangat kurang \\
\hline
\end{tabular}

\section{HASIL DAN PEMBAHASAN}

\subsection{Hasil Penelitian}

Dari hasil penelitain ini diperoleh data tes kemampuan penalaran matematika, berikut disajikan deskripsi hasil analisis tes penalaran matematika siswa SMP Negeri 2 Berubah. seperti terlihat pada table berikut:

Tabel 2 Deskripsi hasil analisis Tes penalaran Matematika

\begin{tabular}{ccccc}
\hline Subjek & $\mathbf{N}$ & $\begin{array}{c}\text { Rata-Rata } \\
\text { Skor }\end{array}$ & Nilai Tertinggi & Nilai Terendah \\
\hline $\begin{array}{c}\text { Siwa kelas } \\
\text { VII A }\end{array}$ & 31 & 46.62 & 80 & 15 \\
\hline
\end{tabular}

Dari table 2 diatas diatas dapat di lihat bahwa rata- rata skor penalaran matematika siswa SMP Negeri 2 Berbah adalah 46,62 dapat di simpulkan bahwa tingkat penalaran matematika siswa masih dalam kategori cukup, sedangkan untuk nilai tertinggi yang didapat siswa 


\section{Hipotenusa}

Journal of Research Mathematics Education VOL.4 NO.12021

dalam tes penalaran adalah 80 jika dilihat dari table 1 maka dapat disimpulkan masih masuk dalam kategori baik, sedangkan untuk nilai terendah yang dapat oleh siswa adalah 15 itu berarti penalaran matematika siswa tersebut masuk dalam kategori sangat kurang. Hasil dari tes penalaran matematika siswa dapat dijabarkan pada table 3 berikut :

Table 3. Hasil penalaran matematika siswa

\begin{tabular}{ccc}
\hline Nilai & Kategori & Jumlah Siswa \\
\hline $81-100$ & Sangat Baik & 0 \\
$61-80$ & Baik & 7 \\
$41-60$ & Cukup & 11 \\
$21-40$ & Kurang & 10 \\
$0-20$ & Sangat kurang & 3 \\
\hline
\end{tabular}

Dari tabel 3 dapat dilihat bahwa sebanyak 3 siswa masih memiliki kemampuan penalaran yang sangat kurang pada pembeljaran matematika, sedangkan sebanyak 10 siswa memiliki kemampuan penalaran matematika yang kurang, 11 siswa memiliki kemampuan penalaran yang cukup dan hanya sebanyak 7 siswa yang memiliki kemampuan penalaran yang baik. Belum ada siswa yang masuk dalam kategori penalaran yang sangat baik dalam mengerjakan soal penalaran yang diberikan. Berikut Deskripsi Persentase penalaran siswa dalam bentuk gambar.

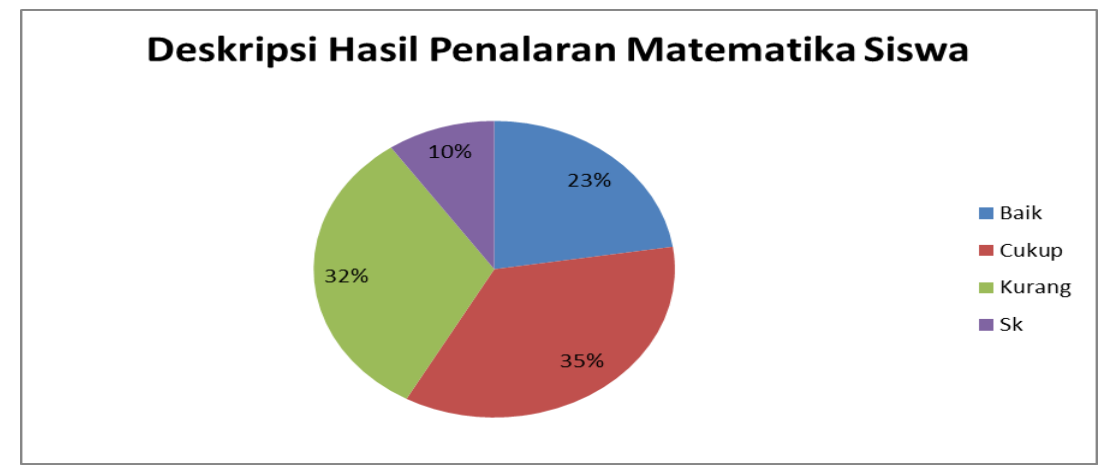

Gambar 1. Deskripsi Persentase penalaran siswa 


\subsection{Pembahasan}

Tujuan dari penelitian iniadalah untuk mengukur seberapa tinggi penalaran matematika siswa kelas VII SMP Negeri 2 Berbah. Dalam penelitian ini materi yang digunakan adalah himpunan. Soal yang diberikan dalam penetilian ini adalah soal esay dengan indikator penalaran yang sebagaimana telah dijelaskan oleh P4TK Yogyakarta di atas.

Siswa dikatakan mampu bernalar atau mempunyai penalaran yang baik apabila siswa tersebut dapat menyimpulkan suatu ide tau gagasan menjadi sebuah kesimpulan yang benar atau dapat dipertanggung jawabkan, berdasarkan analisis data yang telah dilakukan pada 31 siswa yang mengikuti tes ddidapkan rata-rata nilai penalaran sebesar 46.62 \% itu berarti rata-rata siswa masih belum cukup mampu untuk menghasilkan suatu kesimpulan yang valid atau dapat dipertanggung jawabkan.

Dalam penelitian ini siswa diberikan soal penalaran matematika berupa soal esay sebanyak 5 soal dengan materi himpunan. Berdasrkan table 3 dan gambar 1 dapat kita lihat bahwa sebanyak 3 siswa atau 10 \% dari yang mengikuti tes penalaran masih masuk dalam kategori sangat kurang siswa tersebut masih belum mampu untuk melakukan mengikuti indikator penalaran seperti yang telah dijelaskan di P4TK Yogyakarta diatas, sebanyak 10 siswa atau $32 \%$ siswa yang mengikuti tes masih masuk dalam kategori kurang siswa masih memberikan jawaban yang kurang tepat dan tidak memberikan alasan bagaimana jawaban tersebut didapatkan, sebanyak 11 siswa atau 34 \% siswa yang mengikuti tes masuk dalam kategori cukup siswa sudah mampu melakukan manipulasi matematika, mangajukan dugaan namun siswa belum mampu untuk menemukan pola atau sifat untuk menjelaskan mengapa cara yang digunakan adalah benar dan menarik sebuah kesimpulan atau bukti terhadapa kebenaran sebuah sulusi masih belum tepat. Sebanyak 7 siswa atau 23\% sudah memiliki kemampuan penalaran matematika dengan baik atau sudah mengikuti aturan yang terdapat didalam indikator penalaran namun siswa belum mampu untuk menarik sebuah kesimpulan sehingga jawaban meraka 
masih banyak yang kurang tepat dan belum ada siswa di SMP Negeri 2 Berbah yang memiliki penalaran matematika yang sangat baik .

\section{KESIMPULAN DAN SARAN}

Dari hasil peneltian dan pembahasan yang telah dipaparkan di atas dapat disimpulkan bahwa masih banyak siswa yang belum mampu untuk melakukan penalaran matematika dengan baik, siswa masih belum bisa memberikan alasan mengapa jawaban yang diberikan tersebut adalah masuk akal dan juga menggambarkan sebuah kesimpulan dari informasi serta data yang mendukung.

Adapun faktor- faktor penyebab rendahnya penalaran matematika siswa adalah pembelajaran matematika yang kurang bermakna, pembelajaran disana cenderung abstrak atau membosankan siswa hanya mendapat informasi dari guru dan siswa belum bisa mengeluarkan pendapatnya sendiri dikarenakan metode pembelajaran yang diberikan oleh guru masih menggunakan metode yang klasik atau metode expositori

Untuk penelitian lebih lanjut hal - hal yang perlu digali dalam meningkatkan penalaran matematika siswa adalah mencari metode pembelajaran yang tepat yang bisa diterapkan untuk meningkatkan penalaran matematika siswa. 


\section{DAFTAR PUSTAKA}

[1] NCTM. 2000. Principles And Standards For School Mathematics.

[2] Napitupulu, E. Elvis, Didi Suryadi, and Yaya S. Kusumah. 2016. “Cultivating Upper Secondary Students ' Mathematical ReasoningAbility And Attitude Towards Mathematics Through ProblemBased Learning." Journal On Mathematic Education 7(2):117-28.

[3] Shivakumar, T., and Mary Suvarma. 2014. "A Study On Influence Of Reasoning Ability Of Secondary School Students." International Multidisciplinary Reseach Journal 4(1).

[4] Rizqi, Nur Rahmi, and Edy Surya. 2017. "An Analysis Of Students ' Mathematical Reasoning Ability In VIII Grade Of Sabilina Tembung Junior." International Journal Of Advance Research And Innovative Ideas In Education 3(2):3527-33.

[5] Bardini, Caroline, Robyn Pierce, Jill Vincent, and Deborah King. (2014). Undergraduate Mathematics Students' Understanding of The Concept of Function. Journal on Mathematics Education 52 : 85-107.

[6] Hidayat, W., Wahyudin, and S. Rabawanto. 2018. "Improving Students ' Creative Mathematical Reasoning Ability Students Through Adversity Quotient And Argument Driven Inquiry Learning Improving Students ' Creative Mathematical Reasoning Ability Students through Adversity Quotient and Argument Driven Inqu." Journal Of Pshysics : Conference Series (Series 946).

[7] Erdem, Emrullah, and Ramazan Gürbüz. 2015. "An Analysis of Seventh- Grade Students 'Mathematical Reasoning."

[8] TIMSS. 2015. International Results in Mathematics.

[9] Maarif, Samsul. 2016. "Improving Junior High School Students ' Mathematical Analogical Ability Using Discovery Learning Method Improving Junior High School Students ' Mathematical Analogical Ability U Sing." International Journal Of Research In Education And Science 2(1):114-24.

[10] Erdem, Emrullah. 2017. "Age- And Gender-Related Change in Mathematical Reasoning Ability and Some Educational Suggestions." Journal Of Education And Practice 8(7):116-27.

[11] Permendiknas. 2006. Peraaturan Menteri Pendidikan Nasional Nomor 22 Tahun 2006.

[12] Sukirwan, Darhim, and T. Herman. 2018. "Analysis of Students ' 
Mathematical Reasoning Analysis of Students ' Mathematical Reasoning." Journal of Pshysics 948:1-7.

[13] Tamura, Y., T. Umetani, and H. Nakamura. 2017. "Adult Gesture in Collaborative Mathematics Reasoning in Different Ages Adult Gesture in Collaborative Mathematics Reasoning in Different Ages." Journal Of Pshysics 895:1-11.

[14] Wardhani, Sri. 2008. Analisis SI Dan SKL Mata Pelajaran Matematika SMP/MTS Untuk Optimalisasi Tujuan Mata Pelajaran Matematika. 